Kohl: A Journal for Body and Gender Research

Vol. 1, No. 1 (Summer 2015)

\title{
Reconceptualizing Sexual Harassment in Egypt: A Longitudinal Assessment of el-Taharrush el-Ginsy in Arabic Online Forums and Anti-Sexual Harassment Activism
}

\author{
Angie Abdelmonem
}

\begin{abstract}
:
This paper examines shifting conceptualizations of sexual harassment, or el-taharrush el-ginsy, in Egypt. Through longitudinal data from online Arabic discussion boards and blog sites, as well as insights from interviews and participant observation of anti-sexual harassment organizations, it explores the range of meanings evident in the use of the term taharrush. A comparative approach was employed to assess changes in Egyptian discourses with those taking place across the region. Online data was collected using the search terms "taharrush ginsy" and "taharrush." Google served as the primary search engine to locate discussion and blog posts from the years 2000-2012. Through this method, 233 unique posts were identified focused on el-taharrush el-ginsy. The data showed overwhelming public concern in the region about the molestation and rape of children until 2006. In October 2006, a shift occurred in Egyptian posts, tied to the Eid mob sexual harassment that took place in downtown Cairo. From that point on, taharrush in Egypt signified the sexual harassment of women in public space. Prior to the Eid mob sexual harassment event, the Egyptian Center for Women's Rights had begun a campaign to end everyday sexual harassment in the streets, which it called taharrush. Following the 2011 Egyptian Revolution, this activism continued with independent initiatives focused on community-based work, such as HarassMap. Throughout this time, the discourse was complicated by the connection of taharrush to more violent forms of sexual assault and rape, which was further evident following the Revolution. This connection of taharrush with more sexually violent practices aligns with prior meanings of taharrush, but it has also contributed to public resistance to the idea that taharrush signifies everyday sexual harassment that anti-sexual harassment initiatives seek to establish.
\end{abstract}


| 24 In September 2013, members of the Egyptian anti-sexual harassment initiative, HarassMap, participated in the MasterPeace street festival in the upscale Cairene neighborhood of Dokki. MasterPeace is a global grassroots initiative aimed at mobilizing local communities to support peace building through intercultural dialogue. ${ }^{1}$ HarassMap utilized this opportunity to continue to grow their public presence, promote their message about speaking up and intervening against sexual harassment (to not be a bystander), and to recruit new volunteers for community outreach teams. At one point, a heated exchange arose between an older man walking through the street festival and HarassMap members, about the existence of the phenomenon of el- taharrush el-ginsy, or sexual harassment, in Egypt. The crux of the man's argument was that taharrush was not a problem in Egypt. Instead, he noted that $m u$ 'àksa, often translated as flirtation, was prevalent, though he qualified this by stating that mu'āksa also existed in other countries, even America, and was not unique to Egypt, but that taharrush was a "big word" that should not be used lightly. HarassMap members, for their part, approached the man's argument first by asking him if he had daughters and how he felt about the possibility of them being harassed in the street. Then, more excitedly, female volunteers detailed what harassment was really like for women in the streets. However, the man's understanding of, and distinction between, the terms taharrush and mu 'āksa went unexamined and unchallenged by HarassMap members.

Almost a decade earlier, when the Egyptian Center for Women's Rights (ECWR) began the first campaign against street sexual harassment in 2005, public reactions were similar to the older man's comments at the MasterPeace event. From the start, ECWR referred to the phenomenon of sexual harassment as el-taharrush el-ginsy, which was met with confusion, embarrassment, anger, and most often denial. Salient elements of public feedback at the time were that taharrush did not exist in Egypt and that it was an American concept that could not be directly applied in the Egyptian context. Incidentally, this type of criticism also arose in later contexts when HarassMap conducted outreach events. Moreover, people argued the word taharrush was, quite simply, too "big" to signify the phenomena of catcalls, comments, stares, and even touching, that were prevalent in the streets.

These examples demonstrate the tension that existed, and continues to exist, around the naming of sexual harassment as el-taharrush el-ginsy. This paper interrogates this tension by exploring shifting perceptions around the use of el-taharrush al-ginsy among the public, through data derived from online Arabic discussion board forums over a 12-year period that includes pre and post ECWR's anti-sexual campaign dates. Additionally, with data generated by participant observation and interviews, it explores the reformulations of el- taharrush el-ginsy promoted by Egyptian civil society organizations and grassroots initiatives, aligned with international women's rights agendas and discourses centered on combatting violence against women. It is

The findings of this paper derive from the author's forthcoming doctoral dissertation, Anti-Sexual Harassment Activism in Egypt: Transnationalism and the Cultural Politics of Community Mobilizing.

${ }^{1}$ www.masterpeace.org. The 2013 Cairo street festival brought together a number of Egyptian youth-based and community-based organizations promoting activities for community improvement. 
argued here that the tension around el-taharrush el-ginsy in Egypt is linked to its long held association with more violent forms of sexual assault and rape, particularly against children and women and primarily in the private realm of the home, and semi-private spheres of schools and work.

\section{History and Context of Sexual Harassment in Egypt}

Until 2005, sexual harassment was not an identified problem addressed by Egyptian women's advocacy organizations. Early that year, female activists protesting the constitutional referendum outside of the Press Syndicate offices in downtown Cairo were sexually harassed and assaulted by police forces and state hired "baltigiyya," or thugs (Al-Nabaa News 2005; Langohr 2013; Radwan 2011). Following the event, which came to be known as Black Wednesday, reactions were swift from prominent activists and scholars who formed a short-lived movement against political violence, "The Street is Ours," and condemned state efforts to silence dissent, through assaults designed to curtail women's participation in the public sphere by undercutting their respectability (Adly 2013; Amar 2011; Nazra Joint Statement 2012). At the time, however, there was no clear definition or conceptualization, both within civil society and the public-at-large, of what sexual harassment was, as a specific configuration of el-taharrush el-ginsy. An article released on the incident in June 2005 by Al-Nabā News, referenced the Black Wednesday attack as both taharrush and htk' ird, a term for rape that is often translated as "indecent assault" and deeply inhered with connotations of honor and shame (Al-Nabā News 2005). Both taharrush and htk ird were utilized interchangeably in the article, likening the indecent assault on women to an assault on the nation. However, sexual harassment, as it came to be understood in the post-Revolutionary period with both its political and everyday facets, as defined by Tadros (2013b), was not yet part of the larger discourse on gender-based violence in Egypt.

In late 2005, the Egyptian Center for Women's Rights (ECWR) an advocacy NGO, began a program aimed at combatting everyday sexual harassment in the streets (Rizzo 2008 \& 2012). ${ }^{2}$ In 2008, they released their now widely cited study, "Clouds in Egypt's Sky," that gained global attention for documenting for the first time, how widespread sexual harassment was in Cairo's streets, with $83 \%$ of Egyptian and $98 \%$ of foreign women surveyed, indicating that they had experienced sexual harassment (Hassan et al. 2008). The study defined el-taharrush el-ginsy as unwanted behaviors of a sexual nature that were largely non-physical, highlighting seven specific acts including catcalls/noises, ogling, verbal harassment, stalking/following, phone harassment, indecent exposure and even touching. They identified sexual harassment as a primarily social and psychological issue, and also framed it as a security problem for women in public, calling for increased and improved enforcement and reporting processes inside of police stations (ECWR 2009). This framing practice and their approach in highlighting the strictly social nature of sexual harassment was criticized by scholars, for failing to address the larger system of gender inequality within which sexual harassment was situated, and for creating culturally "flawed" Egyptian men (Abu Lughod 2011 \& 2014; Amar 2011).

\footnotetext{
2 See www.ecwr.org to access studies and press releases issued by ECWR on sexual harassment
} 
Prior to the 2011 Revolution, a number of high profile events occurred that helped shape sexual harassment discourses and public conceptions in particular ways. During the 2006 Eid el-Fitr holiday, groups of young men who turned away from a sold out movie at a cinema in the downtown area went on a mass sexual harassment spree, attacking women and girls (llahi 2008). What made this event significant is the fact that it was caught on video by mobile phones and was widely broadcasted via YouTube by prominent Egyptian bloggers, such as Wael Abbas and Malek X. Egyptian bloggers denounced the lack of attention that the Eid mob harassment event, and sexual harassment in general, received from the state and media (Rifaat 2008). Additionally, in 2008, a 27-year-old filmmaker, Noha Rushdie, won the first sexual harassment case to be tried in the Egyptian court system (Amar 2011; llahi 2008). Rushdie's case was won using Article 306 of the penal code, which illegalized any offense against the modesty, honor or dignity of another, or khadsh hayā' (Muslimah Media Watch 2006). Like htk irḍ, khadsh hayā' was linked to the notion that sexual offenses compromise women's honor. As with the Black Wednesday case, El-Youm el-Sāba' News reported that Rushdie's harasser, Sherif Gabril, committed indecent assault (htk irḍ) against her, and el-Mașry el-Youm similarly reported that the Public Prosecutor formally accused Gabril of htk' ird (el-Mașry el-Youm 2008; elYoum el-Sāba' 2010).

In December 2010, the popular movie 678 was released, which was the first feature film produced in Egypt that focused on taharrush as a problem for women in public spaces. Through the stories of three protagonists whose lives intersect around their shared experiences of sexual harassment, the movie featured differing forms of sexual violence comprising taharrush, such as unwanted groping on public transportation, physical assault, and possible rape, and explored a number of themes that showed the impact of these forms of sexual harassment on women. Yet, the film also raised the concerns that it promoted the need for women to defend themselves through violence and that it humiliated Egyptian men (Al-Jazeera 2011). Moreover, it problematically rooted the fundamental reason for sexual harassment in the sexual frustration of men (Egypt Independent 2010).

Following the 2011 Egyptian Revolution, el-taharrush el-ginsy became the focus of increasing attention from the media, activists and scholars. The violent nature of sexual harassment and assault in Tahrir Square captured global attention. In particular, the politicization of sexual violence heightened concerns among activists and scholars, who believed the State was involved in hiring and paying baltigiyya to harass, assault, and rape women in an attempt to drive them away from public protest and participation (Ahmad Zaki \& Abd Alhamid 2014; Langohr 2013). However, in the first 18 days of protest from January 25 to February 11, activists widely noted that sexual harassment was noticeably absent in Tahrir. Vickie Langohr quoted one activist who said "These were the only 18 days in my life in Egypt that I was not harassed at all" (2013: 19). This shifted on February 11, the day Mubarak stepped down, with the mob assault and rape of CBS correspondent, Lara Logan (Replogle 2011). Between 2011 and 2013, sexual harassment became common 
at protests in Tahrir, exemplified by a number of highly publicized violent attacks that demonstrate how women's bodies became objectified and dehumanized during the uprising.

On March 9 2011, the day after International Women's Day, activists flooded into Tahrir Square for a Million Women's March, which ended with the police arresting 17 women activists, including Samira Ibrahim (Hafez 2014; Seikaly 2013). Ibrahim was subject to a state sanctioned virginity test (kashef el- adhariyya), the practice of which was supported by then General el-Sisi as a necessity to protect the military from allegations of rape (Daily News Egypt 2011). Underpinning the virginity tests was a belief among military officials that women at the protests were already disreputable and likely to not be virgins. An anonymous military source noted at the time that the female protestors were not like "your daughter or mine," as many of them camped out with men in Tahrir (Hafez 2014: 174; Langohr 2012: 22). Ibrahim gained widespread attention for speaking up about her experience, but also for taking the military to court to hold them accountable for assaulting her. Also in 2011, a video of the "Blue Bra Girl" (also referred to as Tahrir Girl, Sit al Banat) incident disseminated via YouTube went viral. In the video, an unknown female protestor was shown being dragged by state security forces, her abaya stripped to reveal her bra and then her body trampled. Additionally, like Samira Ibrahim, musician and activist, Yasmine el-Baramawy, spoke up about the violent mob assault and rape (with a knife) against her that occurred in Tahrir in 2013. Baramawy was stripped naked and dragged by car, with her attackers yelling that she had a bomb strapped to her (Langohr 2013).

Such high profile incidences occurred alongside frequent mob attacks that emerged as a feature of Tahrir protest. From November 2012, mob attacks took on a new character as they became more organized, manifesting themselves through the formation of concentric rings of men surrounding a single woman before they stripped and raped her (Ahram Online 2013). In response to the violence targeting women in Tahrir, a number of volunteer initiatives arose to combat mob harassment, assault, and rape in the context of Revolutionary protest. Operation Anti-Sexual Harassment (OpAntish) and Tahrir Bodyguard were two prominent initiatives, comprised of both female and male activists, who worked in tandem to intervene and pull women out of mob attacks. In the nine-day period from June 28 to July 72013 , which witnessed the deposal of the Muslim Brotherhood President Mohamed Morsi, OpAntish noted that there were 186 documented cases of mob sexual harassment, assault, and rape (Kirollos 2013).

In addition to these volunteer initiatives, others also arose either just prior to or after the Revolution, including HarassMap, Shoft Taharrush, Ḥarakat Bașma and Ded el-Taḥarrush. ${ }^{3}$. Like ECWR before them, these initiatives focused their work primarily in the streets and within communities, the goal of which was to refashion social perceptions of and behaviors relating to everyday sexual harassment. The Revolution provided a unique political opportunity for such community and street-based approaches to combat public

\footnotetext{
${ }^{3}$ HarassMap website - www.harassmap.org; Shoft Taharush website - www.isawharassment.org/arl; Harakat Bașma on Facebook - https://www.facebook.com/Imprint.Movement.eg?fref=ts; Ded el-Taharrush on Facebook - https://www.facebook.com/ded.taharosh?fref=ts
} 
| 28 sexual harassment, including the greater use of technological means to spread awareness and organize street outreach activities (ElSayed \& Rizzo 2014). Other organizations, such as Nazra for Feminist Studies, the El-Nadim Center for the Rehabiliation of Victims of Violence and Torture, and the Egyptian Initiative for Personal Rights (EIPR), similarly included taharrush within their programs combatting gender based violence overall, with much attention centered on politicized sexual violence, legal advocacy, and promoting a national strategy to combat all forms of gender-based violence (Langohr 2014) ${ }^{4}$.

These events have served as critical markers in the history of sexual harassment in Egypt, demonstrating wide variability in the discourses on taharrush. In an interesting discursive turn, el-taharrush el-ginsy is increasingly a facet of, as well as synonymous and interchangeable with a more general notion of gender violence (el-' unf did el-marāa) in activist rhetoric. Recounting her own experiences of being detained, beaten, and assaulted by police, journalist Mona el-Tahawy noted, "I'm so used to saying harassment, but they assaulted me" (The Guardian 2011).

While it may be possible to question the need to differentiate forms of sexual violence, the lack of conceptual boundaries around taharrush helps to reproduce public resistance to the fact that everyday forms of sexual harassment are equivalent in gravity to assault and rape. Yet, it does not fully explain the resistance highlighted at the outset of this paper. The denial of the existence of el-taharrush el-ginsy, and the distinctions made between taharrush and mu' aksa by the gentleman at the MasterPeace street festival, signal deeper circuits of meaning that both intersect and conflict with current reformulations of sexual harassment as everyday sexual harassment, and which necessitate further exploration. At stake, in this exploration of the underlying basis for public denials of the existence of el-taharrush el-ginsy, is the success of anti-sexual harassment initiatives at reframing sexual harassment as a form of violence that prevents women from full participation in the public space.

\section{Research Questions and Data}

This paper asks two central questions: 1) how has el-taharrush el-ginsy been discursively employed by the public before and after the start of anti-sexual harassment activism, and 2) how and why has anti-sexual harassment activism reformulated el-taharrush el-ginsy, i.e. what was the purpose of such active reformulations? These questions investigate the differential discursive uses of el-taharrush el-ginsy over time to gain a better appreciation of the meanings inherent in the term. Given historic public conceptions of eltaharrush el-ginsy, these questions interrogate how this term came to signify public sexual violence, as it is understood today.

\footnotetext{
${ }^{4}$ Nazra for Feminist Studies website - http://nazra.org/en; El-Nadim Center website - http://alnadeem.org/en/node/23; EIPR website http://www.eipr.org/en
} 
Two lines of data are employed to answer these questions. Data derived from online Arabic discussion forums and blog sites between the years 2000-2012 represent a unique archive and provide a longitudinal view of public sentiments on el-taharrush el-ginsy. The primary search tool utilized to obtain such posts was Google. Two Arabic search terms were employed to trawl for discussion forum and blog data, including "taharrush ginsy," and "taharrush."

Discussion forum and blog data that was generated through this approach spanned much of the Middle East and North Africa. In total, 233 posts were located from 107 sites across 18 countries. Data from other Arabic speaking countries was included largely, given the paucity of online data from Egypt prior to 2005. The use of data from across the region offered the ability to look at change comparatively and to deduce critical preliminary observations about conceptual changes happening inside of Egypt. Future analyses of posts from other social media forums, especially Facebook and Twitter, as well as mass media outlets, such as print and broadcast news, would provide more nuanced insight of the various conceptualizations and the circulation of discourses on taharrush, and how those discourses may be internalized by the population.

Additionally, insights were derived from data obtained through interviews with prominent activists in antisexual harassment organizations, including ECWR and HarassMap, as well as participant observation conducted over one year, between 2013 and 2014, with HarassMap. Such data was examined in parallel with online discussion forum and blog data to interrogate how Egyptian civil society entities have been reframing el-taharrush el-ginsy.

\section{Characteristics and Demographics of Arabic Discussion Board Posts}

Discussion forums and blog posts make visible the changes in public conceptualizations of sexual harassment in Egypt, particularly when compared to those of other parts of the region. The distribution of posts across countries is shown in Figure 1. Points of origin for most posts were identified based on the stated country of origin of the forum member, or on the national orientation of the discussion forum or blog. When specific countries could not be found and national orientation of the site could not be determined, more general areas were listed, such as "Gulf," which were often determined based on regional indicators or peculiarities of dialect inherent in the text of the posts. The majority of posts derived from Egypt, Saudi Arabia, and the Gulf area, representing $77 \%$ of the sample. Here, "Gulf" includes a number of potential Persian Gulf countries, but it may be possible to presume that many of these posts derive from Saudi nationals, given their high rate of participation in discussion forums. It is clear, though, that individuals from across the region participated in discussions of el-taharrush el-ginsy, although their prevalence is comparatively low. This suggests that Egypt and Saudi Arabia are central loci for the development of national and cross-national discursive configurations of sexual harassment.

Figures 2 and 3 include the distribution of posts over time; Figure 2 for all posts from across the region and Figure 3 for those posts originating from Egypt. Overall numbers from year to year are relatively low, however, 
1 30 an increase in the discussions of el-taharrush el-ginsy is apparent from 2004 and peaks between 2005 and 2006, as noted in Figure 2. The number of posts then slowly decreases from 2007 but does not get as low as pre-2005 numbers. It is not clear why there are fewer posts prior to 2004 , but possible explanations include the fact that conversations about el-taharrush el-ginsy were rare or not happening in online communities, or that this data was not recoverable through Google. In Egypt, the discussion on el-taharrush el-ginsy mirrors the regional trend, to some extent. It is noticeable from 2003, but remains minimal until 2006. As shown in Figure 3, there are 7 posts in total between 2003 and 2005, and the number jumps to 21 in 2006, which represents a $200 \%$ increase in the discussion on sexual harassment between these years.

\section{Thematic Content of Discussions on el-Taharrush el-Ginsy}

All posts were analyzed for thematic content and a codebook was developed in order to code and quantify the prevalence of certain themes inherent in the text of people's conversations. Twelve themes emerged from all posts, as visible in Table 1. A single post received multiple codes depending on the nature of the discussion, which often cut across a range of issues, and resulted in a total of 670 coded instances across the 233 posts. Two highly significant thematic areas in the discussion of el-taharrush el-ginsy focused on children and women. As highlighted in Table 1, $57 \%$ of all posts were coded as child molestation/rape, and $42 \%$ as the sexual harassment of women. Egypt shows an inverse trend, with a higher focus on the sexual harassment of women at $66 \%$, and a lower focus on child molestation/rape at $32 \%$. As will be discussed, this trend is potentially linked to the anti-sexual harassment efforts that began in 2005. Salient elements of the discussion around the themes of children and women include:

Child Molestation/Rape - This code represented more than half of the conversations that revolved around el-taharrush el-ginsy across the region. There was overwhelming concern with child sexual assault within families, followed by that in schools and, with particular reference to Saudi Arabia and the Gulf, the assault on children by domestic employees, such as drivers and maids. El- taharrush el-ginsy in this context was viewed as both a violation of children's bodies, but also an act with devastating consequences for children. This was especially the case for the molestation and rape of young boys, where fears were evident that such an act would lead to sexual deviance, such as homosexuality, sodomy, and masturbation. Child molestation/rape and homosexuality co-occurred more than any other two codes that were analyzed, with the exception of parental awareness/responsibility. Within this context, posts often exhorted parents to not leave children alone unguarded, to teach their children unacceptable forms of touching, and offered advice and support to those whose children had been the victims of sexual molestation and rape.

Sexual Harassment of Women - This was also a prevalent theme in discussions of el-taharrush el-ginsy, representing almost half of the posts region-wide, and about two-thirds of the posts from Egypt. It is important here to note that this theme overlapped significantly with the molestation and rape of children, where many 
discussions focused on the abuse of adolescent and teen girls by fathers, stepfathers, uncles, cousins, and in some cases grandfathers and brothers. There were divergent trends in the discussion on women, focused both on sexual abuse at home and work, and sexual harassment in public settings, especially in the street or on transportation. In Egypt, the majority of posts focused on women's public sexual harassment, mostly described as physical in nature, including touching, rubbing, and groping. However, verbal harassment that was vulgar and sexual in orientation also arose in online conversations. Individuals contested the role of dress in promoting sexual harassment, with many placing the blame on women for going out without the minimal protection of hijab. In the workplace, discussions centered on women's lack of power, being propositioned by bosses, and leaving employment to avoid further unwanted advances.

Beyond these two dominant themes around el-taharrush el-ginsy, others were also critical. Rape arose in conversations and was viewed as a problem in families, schools, and the workplace. It was sometimes linked to homosexuality, particularly where rape and sexual harassment targeted young boys or men. This theme was also connected to the public sexual harassment of women, where individuals debated the role of clothing as an underlying cause of the problem and argued it to be a psychological disease. Moreover, zinā, or adultery, and illicit sexual relationships, emerged as significant, notably in Saudi Arabia and the Gulf. Such relations were usually presented as a consensual, negative and, demoralizing, practice.

$M u$ 'āksa, or flirtation, similarly came up in discussions. Though a largely Egyptian term, it appears as "elmu 'āksa" or " $t$ 'ākis" in 3 posts from Saudi Arabia, 3 from the Gulf, and 1 from Qatar. For instance, a selfidentified Saudi male participant on the discussion forum al-Hayā al-Zawjïya, explored how he felt responsible for sexual harassment, arguing that the blame did not rest on girls for the "tașarafāt al-shāb alshādha wa mumarāstu lil-mu'āksa wa al-taḥarrush" (flirting and harassing behaviors of abnormal men). Mu 'àksa overwhelmingly co-occurred with the code for the sexual harassment of women. It was often used synonymously with taharrush, but was also presented in multiple and conflicting ways. It was a reference for physical forms of sexual harassment, rape, and sexual relations, and was also used to denote verbal harassment and compliments to women.

Power, control and authority were likewise important talking points, especially in Egypt, and included critiques of the authoritarian system, the patriarchal society, women's vulnerability and inferiority to men, women's fear of being fired, and social blame placed on women for their sexual harassment. Lastly, the sexual harassment of men that was not connected to the abuse of young boys, could limitedly be found in some conversations that recognized that women could be harassers, but more often still linked harassed men to homosexuality. 


\section{| 32 Temporal Shifts in Discussions of el-Taharrush el-Ginsy}

Exploring the distribution of these codes over time, a number of trends are visible that provide valuable insights on changing conceptualizations of el-taharrush el-ginsy. Figure 4 demonstrates the prevalence of child molestation and rape throughout the majority of the 12-year timespan under analysis, with peaks in online discussions between 2005-2009. Overall, it remained a consistent part of the conversation. Figure 5 highlights that this distribution holds true for Egypt where, from 2003 to 2012, this theme remained a present, even if a small, part of the dialogue.

The distribution of the code for the sexual harassment of women, displayed in Figure 6, also spans the majority of the time range within the region, but prior to 2003 it was not part of the discourse on el-taharrush el-ginsy. When it became visible in 2003, public concern was about incest, the assault on young women by male relatives, women's vulnerability in the workplace and in hospitals, and even the harassment and rape of females at Abu Ghraib prison. In Egypt, the sexual harassment of women appears as a code early in 2006. In this year, there was a general peak in the conversations focused on the sexual harassment of women in the last quarter of 2006, with the majority of such posts (15 of 18) deriving from Egypt, as visible in Figure 7. At this point, el-taharrush el-ginsy was used to reference the mob sexual harassment that occurred around the Eid holiday in October 2006. Subsequent posts from Egypt centered on women's sexual harassment in the streets and on transportation.

As noted previously, the Eid mob harassment that took place in downtown Cairo, which has since become a yearly ritual, generated a wide degree of attention in the media and the Egyptian blogosphere, which was similarly matched with public deliberations via discussion forums on the event (Rifaat 2008; Rizzo et al. 2012). It was from this historic moment, that sexual harassment targeting women in the streets became a vital part of how el-taharrush el-ginsy was conceptualized. In Egypt, this was interlaced with the continued yet miniscule use of taharrush to refer to child sexual assault, as well as fluctuating use with respect to rape and mu'āksa. Outside of Egypt, child sexual assault still dominated conversations on taḥarrush.

\section{Reconceptualizing el-Taharrush el-Ginsy}

Returning now to the examples at the beginning of this paper, how does online discussion forum and blogsite data help explain people's discomfort with the term el taharrush el-ginsy? Historically, el-taharrush el-ginsy, in the popular imagination across the region, has been intrinsically associated with and understood as child sexual assault and rape, largely occurring in the private sphere of the home and often committed by trusted individuals. Here, taharrush was overwhelmingly viewed as the physical violation of the body, and was frequently a reference for rape. Moreover, child sexual abuse, particularly that of boys but in some cases of girls, generated high levels of anxiety that taharrush would result later in psychological problems and sexually 
deviant practices, such as masturbation and homosexuality, that would negatively impact children's lives. When applied to women in private and later public settings, this term conveyed similar notions of violence, violation, exploitation, illicitness, and demoralization, with long lasting consequences.

In 2005, when ECWR began addressing street sexual harassment targeting women in Egypt, taharrush, mu 'àksa, zinā, and rape, as well as child molestation, were part of a nebulous constellation of sexually deviant practices with loose and obscured terminological borders. In an interview with Nehad Aboul Komsan, the Director of ECWR, she noted that when they began their program, taharrush was a harsh term that people often conflated with rape. Mu 'āksa, which was (and still is) more commonly deployed and understood to describe attentions directed toward women in the street, was not a term, she argued, that had the power to mobilize people. Mu 'āksa was popularly understood as "a more or less ritualized performance of courtship," which always occurred in public in Egypt's loosely gender-segregated society (Ryzova 2005: 108). It was always seemingly consensual, with the bint al-balad knowing how to flaunt her charms in ways that approached but did not cross the boundaries of the acceptable. Aboul Komsan stated that there was a level of tolerance for $m u$ 'àksa given its widespread association with teasing, flirting, and courtship, and that nobody would ever see mu'āksa as a crime. Criminalizing harassing behaviors, such as catcalls, comments, following/stalking, and touching, was the end goal of the efforts of ECWR, as well as other anti-sexual harassment initiatives like HarassMap. Concomitant with this were ECWR's attempts to refashion social perceptions that these behaviors were non-threatening, non-problematic, a public form of courtship, and the normal actions of libidinous men in an economically depressed and sexually repressed society. El-taharrush el-ginsy provided the conceptual power ECWR and other civil society and grassroots entities needed, to reshape public perceptions around ostensibly benign yet sexualized street behaviors, turning them instead into violent, violating, and criminal bodily practices.

The struggle to promote sexual harassment as violence exists within a larger field of transnational women's rights activism centered on combatting violence against women (Merry 2009 \& 2006). The 1993 UN Conference on Human Rights in Vienna and the 1995 UN World Conference on Women in Beijing set the stage for the increased global focus on gender violence as one of the most concerning forms of genderbased inequality, and Egyptian women's advocacy NGOs have been active players in this arena (Al-Ali 2000; Friedman 1994 \& 2003; Starchursky 2013). Definitions of sexual harassment employed by varying anti-sexual harassment organizations align with global discourses on women's rights. HarassMap pulled most directly from UN definitions of sexual harassment, which was similarly utilized by Nazra for Feminist Studies in their concept paper on the different forms of sexual violence (Nazra 2014). ECWR's definition situated el-taharrush el-ginsy within an uneven power arrangement, where men were able to target women for sexual harassment. Their focus on gendered power mirrored that of American, and to some extent European, women's rights activists, who claimed sexual harassment to be sex discrimination - that is, discrimination specifically targeting women because on their sex - that violated women's economic rights (Baker 2007; Zippel 2006). 
| 34 Promoting sexual harassment as a crime further coheres with the efforts of both Egyptian women's advocacy NGOs to redefine gender violence in the law, as well as their involvement in transnationally inspired efforts to compel state compliance with international conventions, such as CEDAW. In 2008, 16 NGOs formed the Taskforce for the Prohibition of Sexual Violence, coordinated by the New Women Foundation, whose mission was advocating for and drafting amendments to penal code articles centered on gender-based violences. Their draft amendment set better definitions and punishments for various forms of gender-based violence, and attempted to remove notions of honor that prevented women from speaking up against the violence they suffered (FIDH 2014). ECWR, as a member of the Taskforce, similarly put forward its own draft amendment, focused specifically on adding taharrush to the law (FIDH 2014). In 2014, the Egyptian government approved an amendment on el-taharrush el-ginsy to Article 306 of the penal code, which was more generally centered on the offense of modesty (khadsh el-hayā). This occurred following a high profile incident, at the Cairo University College of Law, where a large group of men sexually harassed a young woman, whom police then had to escort off campus (Mada Masr 2014). The public backlash, as well as the activism of a concerned group of Cairo University faculty and anti-sexual harassment initiatives, prompted the government to action, though not in coordination with the Taskforce. Women's NGOs have since criticized the new amendment for limiting sexual harassment to its sexual or pornographic nature, as well as to the context of stalking and following (El-Rifae 2014).

Despite ongoing legal advocacy, the reframing of sexual harassment has been complicated by Egypt's patriarchal and conservative atmosphere, as well as by the lack of definite boundaries around el-taharrush el-ginsy. Early on, ECWR made efforts to establish terminological boundaries between different forms of violence, including el-taharrush el-ginsy and rape (ightașab \& htk irḍ), as evidenced in their report on the cultural forms and legal gaps around sexual harassment in the Arab region (2009). At the end of 2013, a joint campaign, șalaḥhā fĩ dimāghak (Fix It In Your Head/Get It Right), organized by Nazra for Feminist Studies, the Egyptian Initiative for Personal Rights, HarassMap, and Tahrir Bodyguard was launched, that sought to "call it like it is" and solidify terminological definitions. As part of this campaign, catcalls, staring, stalking/following, and indecent exposure were among the many acts that were defined as taharrush, and taharrush was differentiated from assault and rape. Following the campaign, Nazra released the above mentioned concept paper, where sexual harassment, assault, and rape were explicitly distinguished from one another (Nazra 2014).

Yet, particularly since the Revolution, el-taharrush el-ginsy has become a reference for various forms of public sexual violence, which encompass a wide range of behaviors that go beyond the everyday, seemingly benign (less violent) behaviors that were initially the focus of activism when ECWR began their work in 2005. Assaults and rapes have been part and parcel of the story of el-taharrush el-ginsy, as noted at the beginning of this paper which detailed numerous high profile events that have become key markers usually recounted in Egypt's history of sexual harassment, from the Black Wednesday assaults to the Tahrir mob attacks and

${ }^{5}$ The New Woman Foundation Center website - $\mathrm{http}: / /$ nwrcegypt.org/en/ 
rapes (Langohr 2013; Rizzo 2012; Tadros 2013a\&B). The violence in these acts is in keeping with the violence in historic, normative notions of taharrush, but it has complicated the ability of civil society to confront everyday forms of sexual harassment that impede women's ability to safely move through the streets. Everyday sexual harassment is still largely dismissed as simple acts of boys and men joking or playing, or as wanted and sought by women based on the way they dress, walk, and comport themselves (inappropriately) in public.

\section{Conclusion}

El-taharrush el-ginsy has been widely understood in Egypt and the Middle East in two distinct, yet overlapping, ways: as the molestation and rape of children, where fears have abounded that such acts would lead to homosexuality and other forms of sexual deviance, and as the sexual harassment of women, both within the private realm of the home and the public realm of the street. Since 2005, activism has exclusively employed el-taharrush el-ginsy as the sexual harassment of women in public, with many community-based anti-sexual harassment initiatives, such as ECWR and HarassMap, seeking to associate violence with seemingly benign behaviors in order to criminalize and change social perceptions around such behaviors. In the early years of this activism, the focus was largely on everyday forms of sexual harassment prevalent in the street, such as catcalls, comments, stares, following, and touching. Yet, other forms of sexual violence that occurred were likewise included in civil society discussions of taharrush, such as mob sexual assaults and even rape. With the advent of the Revolution in 2011, el-taharrush el-ginsy was deployed to encompass an increasing range of sexually violent behaviors, including more violent forms of assault and even rape, despite civil society efforts to distinguish rape as a separate concept from taharrush. Such violence, to some extent, aligns with historic understandings of taharrush, as demonstrated in online Arabic discussion boards, which center on violent bodily violations and rape. While taharrush has become far more mainstream in public discourses, public conceptions still draw distinctions between taharrush and mu 'āksa, and the everyday forms of sexual harassment have continued unabated for Egyptian women. 
Kohl 1.1

\section{| $36 \quad$ References}

Adly, Magda. "Sexual Assault and Rape in Tahrir Square and its Vicinity: A Compendium of Sources 20112013." Joint Report, El-Nadeem Center for the Rehabilitation of Victims of Violence and Torture, Nazra for Feminist Studies, and New Women Foundation. 2013. Print.

Ahmad Zaiki, Hind \& Dalia Abd Alhamid. "Women as Fair Game in the Public Sphere: A Critical Introduction for Understanding Sexual Violence and Methods of Resistance." Jadaliyya, 7-9-2014. Last accessed 4-16-2015. http://www.jadaliyya.com/pages/index/18455/women-as-fair-game-in-the-publicsphere_a-critical

Ahram Online. "The Circle of Hell: Inside Tahrir's Mob Sexual Assault Epidemic." 2-21-2013. Last accessed 4-19-2015. http://english.ahram.org.eg/NewsContent/1/151/65115/Egypt/Features/The-circle-ofhell-Inside-Tahrirs-mob-sexual-assau.aspx

Al-Ali, Nadje. Secularism, Gender and the State in the Middle East: The Egyptian Women's Movement. Cambridge: Cambridge University Press.

Al-Bab.com. "The Internet in Arab Countries." 2009, Last Accessed 11-10-2014. http://www.albab.com/media/internet.htm

Al-Jazeera. 2011. "Film 678...A Cry Against Harassment" (In Arabic). 1-11-2011. Last accessed 4-16-2015. http://www.aljazeera.net/news/cultureandart/2011/1/111/التحرش-ضد-صرخة-678

Al-Nabaa Information Service. "Al-Taharush: Hatk 3ard Al-Muwatanat Htk Lilwatan." June 2, 2005. Last accessed 1-18-2015. http://www.annabaa.org/nbanews/47/261.htm

Amar, Paul. "Turning the Gendered Politics of the Security State Inside Out?" International Feminist Journal of Politics. 2011, 13(3): 299-328.

Baker, Carrie N. The Women's Movement Against Sexual Harassment. Cambridge: Cambridge University Press. 2007.

Daily News Egypt. "Military Intelligence Head Says Virginity Tests Conducted Out of Self-Defense: Amnesty." 6-26-2011. Last Accessed 4-16-2015. http://www.dailynewsegypt.com/2011/06/26/head-of-militaryintelligence-confirms-virginity-tests-conducted-out-of-self-defense/

Egypt Independent. "678: Sexual Harassment in a Movie." 12-17-2010. Last accessed 4-16-2015. http://www.egyptindependent.com/news/678-sexual-harassment-movie

Egyptian Center for Women's Rights. "Sexual Harassment in the Arab Region: Cultural Forms and Legal Gaps." (In Arabic). 2009. Print.

Eitling, Bruce, John Kelly, Robert Faris, and John Palfrey. "Mapping the Arabic Blogosphere: Politics and Dissent Online." New Media \& Society. 2010, 12(8): 1225-1243.

El-Mașry el-Youm. "Tunshur ḥythiyāt al- ḥakim fi qaḍiyat el-taḥarrush el-ginsy (Judicial Rationale Published in Sexual Harassment Case)." 11-25-2008. Last accessed 4-19-2015. http://today.almasryalyoum.com/article2.aspx?ArticlelD $=187753$

El-Rifae, Yasmin. "Egypt's Sexual Harassment Law: An Ineffective Measure to End Sexual Violence." Middle East Institute. 7-17-2014. Last accessed 3-8-2015. http://www.mei.edu/content/at/egypts-sexualharassment-law-insufficient-measure-end-sexual-violence 
ElSayed, Heba \& Helen Rizzo. "Media, Political Opportunity, and the Anti-Sexual Harassment Campaign." Unpublished manuscript. 2014.

El-Youm el-Sāba'. "Tayyid al-ḥakim 'ala el-mutaḥarrish bil-fatāa Noha Rushdy (Judgment Upheld for the harasser of Noha Rushdie)." 2-15-2010. Last accessed 4-19-2015.

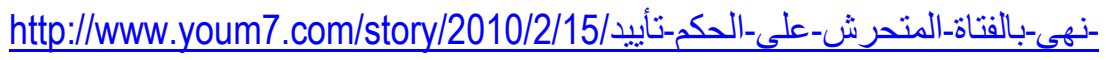
رند/190042\#.VTPSJkujPEk

FIDH, Nazra for Feminist Studies, New Women Foundation, \& Uprising of Women in the Arab World. "Egypt: Keeping Women Out. Sexual Violence Against Women in the Public Sphere." Joint Report. 2014. Last accessed 1-29-105. https://www.fidh.org//MG/pdf/egypt_women_final_english.pdf

Finn, Jerry. "An Exploration of Helping Processes in an Online Self-Help Group Focusing on Issues of Disability." Health \& Social Work. 1999, 24(3): 220-231.

Gersch, Beate. "Gender at the Crossroads: The Internet as Cultural Text." Journal of Communication Inquiry. 1998, 22(3): 306-321.

Hafez, Sherine. "The Revolution Shall Not Pass Through Women's Bodies: Egypt, Uprising and Gender Politics." The Journal of North African Studies. 2014, 19(2): 172-185.

Hassan, Rasha, Shoukry, Aliyaa \& Abul Komsan, Nehad. "Clouds in Egypt's Sky: Sexual Harassment: From Verbal Harassment to Rape." ECWR Report. 1998. Last accessed 3-8-2015. http://egypt.unfpa.org//mages/Publication/2010_03/6eeeb05a-3040-42d2-9e1c-2bd2e1ac8cac.pdf

Ilahi, Nadia. "You Got to Fight for Your Rights: Street Harassment and Its Relationship to Gendered Violence, Civil Society, and Gendered Negotiations." MA Thesis, Dept of Anthropology, Sociology, Psychology and Egyptology, American University in Cairo. 2008. Last accessed 1-19-2015. http://dar.aucegypt.edu/bitstream/handle/10526/3259/llahi_Thesis_AUC.pdf?sequence=1

Kirollos, Mariam. "Sexual Violence in Egypt: Myths and Realities." Jadaliyya, 7-16-2013. Last accessed 416-2015. http://www.jadaliyya.com/pages/index/13007/sexual-violence-in-egypt_myths-andrealities-

Langohr, Vickie. "New President, Old Pattern of Sexual Violence in Egypt." MERIP, 7-7-2014. Last Accessed 4-16-2015. http://www.merip.org/mero/mero070714

--.. "This is Our Square:' Fighting Sexual Assault at Cairo Protests." Middle East Report. 2013, 238 (Fall): 18-35. http://www.merip.org/mer/mer268/our-square

Mada Masr. "Victim Blamed After Sexual Assault at Cairo University." Mada Masr, 3-18-2014. 2014. Last accessed 1-22-2015. http://www.madamasr.com/ar/node/2410

Madhavan, Jayant, David Ko, Lucja Kot, Vignesh Ganapathy, Alex Rasmussen, \& Alan Halevy. "Google's Deep Web Crawl." Proceedings of the VLDB Endowment. 2008, 1(2): 1241-1252.

Mohamed Bin Rashid School of Government \& Bayt. "The Arab World Online 2014: Trends in Internet and Mobile Usage in the Arab Region." Arab Social Media Report series. 2014. Last accessed 11-102014. http://www.mbrsg.ae/getattachment/ff70c2c5-0fce-405d-b23f-93c198d4ca44/The-ArabWorld-Online-2014-Trends-in-Internet-and.aspx

Muslimah Media Watch Blog. "Harassment = Jail Time!" 10-23-2008. Last accessed 1-22-2015. http://www.patheos.com/blogs/mmw/2008/10/harassment-jail-time/ 
Kohl 1.1

| 38 Nazra for Feminist Studies. "Concept Paper: Different Practices of Violence Against Women." 2-5-2014. Last accessed 3-8-2015. http://nazra.org/en/2014/02/concept-paper-different-practices-sexual-violenceagainst-women

---. "The President, His Group, and the Government Must Cease Their Policy in Targeting Female Activists and Excluding Women from the Public Sphere." Joint Statement. 12-12-2012. Last accessed 1-182015. http://nazra.org/en/2012/12/president-his-group-must-cease-their-policy-targeting-femaleactivists-excluding-women

Najork, Marc \& Janet L. Wiener. "Breadth-First Search Crawling Yields High Quality Pages." Proceedings of the $10^{\text {th }}$ International Conference on the World Wide Web. ACM, 2001.

Radwan, Noha. "How Egyptian Women Took Back the Street Between Two 'Black Wednesdays': A First Person Account." Jadaliyya, 2-20-2011. Last accessed 3-8-2015. http://www.jadaliyya.com/pages/index/694/how-egyptian-women-took-back-the-street-between-tw

Replogle, Elaine. "Reference Groups, Mob Mentality, and Bystander Intervention: A Sociological Analysis of the Lara Logan Case." Sociological Forum, 2011, 26(4): 796-805.

Rifaat, Y. "Blogging the Body: The Case of Egypt." Surfacing, 51. 2008. Last accessed. 11-18-2014. https://dar.aucegypt.edu/bitstream/handle/10526/2667/SurfacingVol1No1.pdf?sequence=1\#page= $\underline{59}$

Rizzo, Helen, Price, Anne M., \& Meyer, Katherine. "Anti-Sexual Harassment Campaign in Egypt." Mobilization: An International Journal. 2012, 17(4): 457-475.

--.. "Targeting Cultural Change in Repressive Environments: The Campaign against Sexual Harassment in Egypt." Egyptian Center for Women's Rights Report. 2008. Last accessed 3-8-2015. http://ecwronline.org/pdf/studies/AntiHarassment_for_ECWR.pdf

Ryzova, Lucie. "I am a Whore But I Will Be a Good Mother': On the Production and Consumption of the Female Body in Modern Egypt." Arab Studies Journal. 2004/2005, 12/13(2//1): 80-122.

Seikaly, Sherene. 2013. "The Meaning of Revolution: On Samira Ibrahim." Jadaliyya, 1-28-2013. Last accessed 4-16-2015. http://www.jadaliyya.com/pages/index/9814/the-meaning-of-revolution_onsamira-ibrahim

Tadros, Mariz. "Whose Shame Is It? The Politics of Sexual Assault in Morsi's Egypt." Heinrich Boll Stiftung, Afrique Du Nord Tunis. 2013a. Last accessed 3-8-2015. http://tn.boell.org/downloads/MarizTadros.pdf

--. "Politically Motivated Sexual Assault and the Law in Violent Transitions: A Case Study From Egypt." Institute of Development Studies. 2013b. Last accessed 3-8-2015. http://opendocs.ids.ac.uk/opendocs/bitstream/handle/123456789/2950/ER8\%20final\%20online.pdf ?sequence $=1 \& u t m \_s o u r c e=i d s w e b s i t e \& u t m \_$medium=download\&utm_campaign=opendocs

The Guardian News. 2011. "Journalist Mona Eltahawy Tells of Sex Assault in Cairo Ministry." 11-24-2011. Last Accessed 4-16-2015. http://www.theguardian.com/world/2011/nov/24/journalist-monaeltahawy-sex-assault-cairo

Zippel, Kathrin S. The Politics of Sexual Harassment: A Comparative Study of the United States, the European Union, and Germany. Cambridge: Cambridge University Press. 2006 


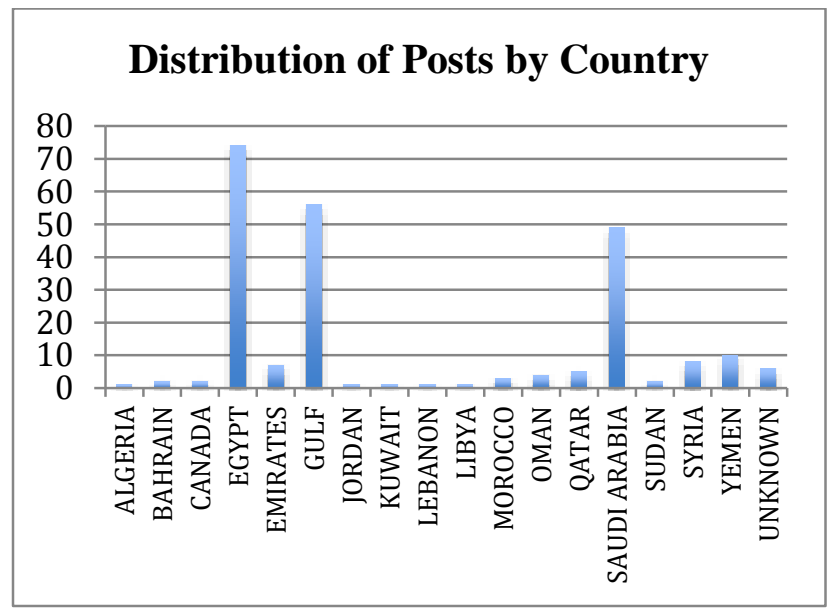

Figure 1: Distribution of All Posts by Location

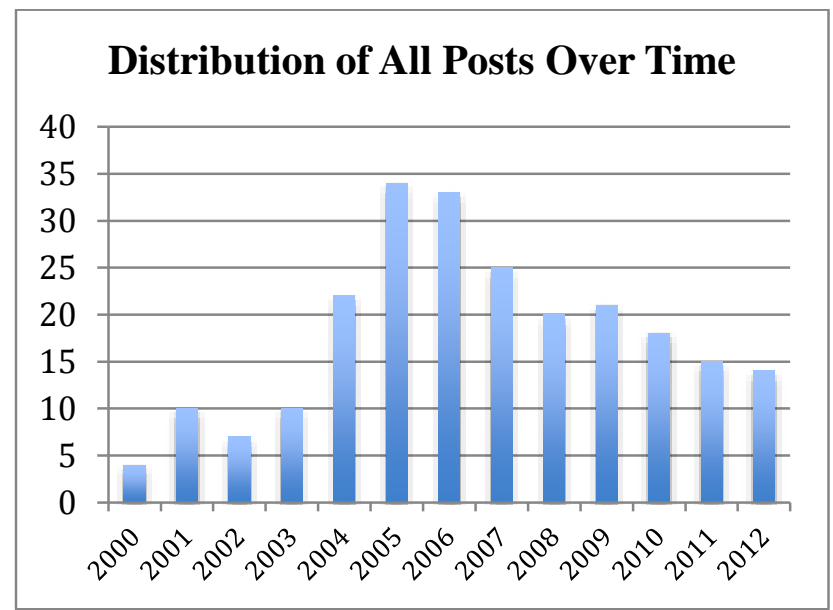

Figure 2: Distribution of All Posts by Year

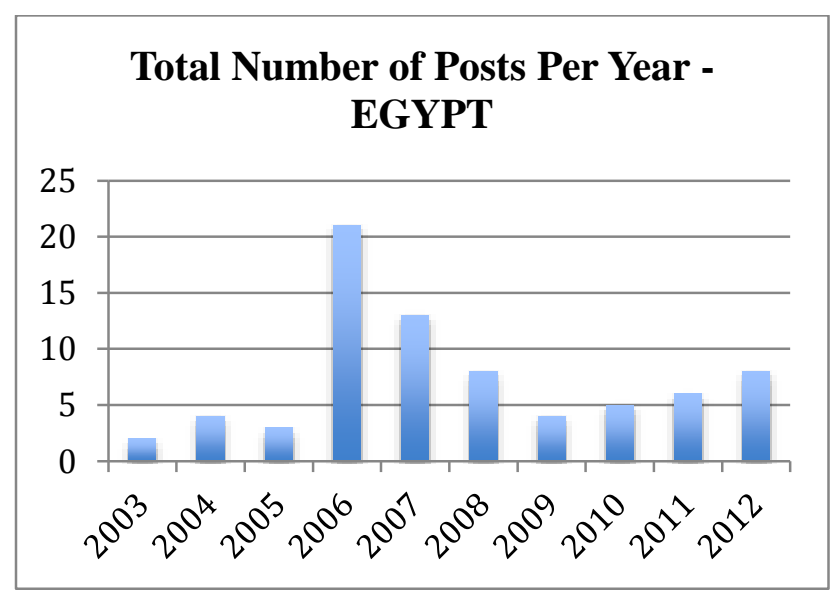

Figure 3: Distribution of Egyptian Posts By Year 


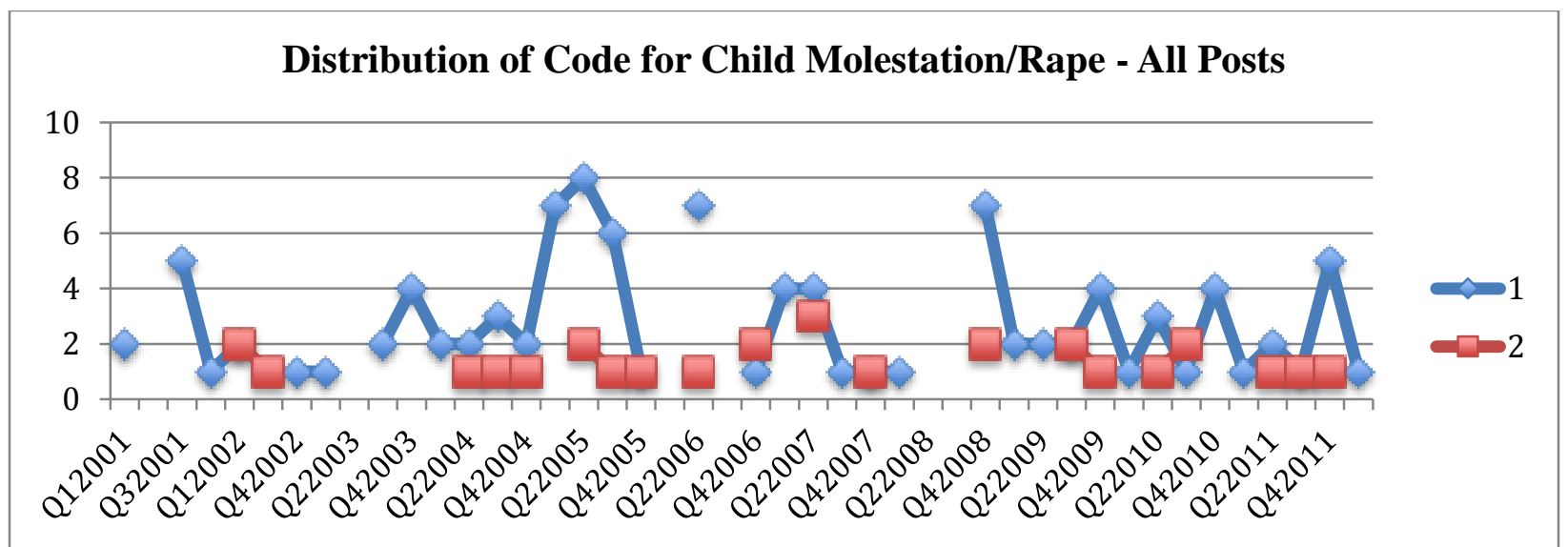

Figure 4: Distribution of All Posts Coded as "Child Molestation" (Blue) and "Child Rape" (Red) By Year. In order to condense data take to create more clear distributions, years were divided into quarters. Each post was assigned a quarter based its month and year of issuance.

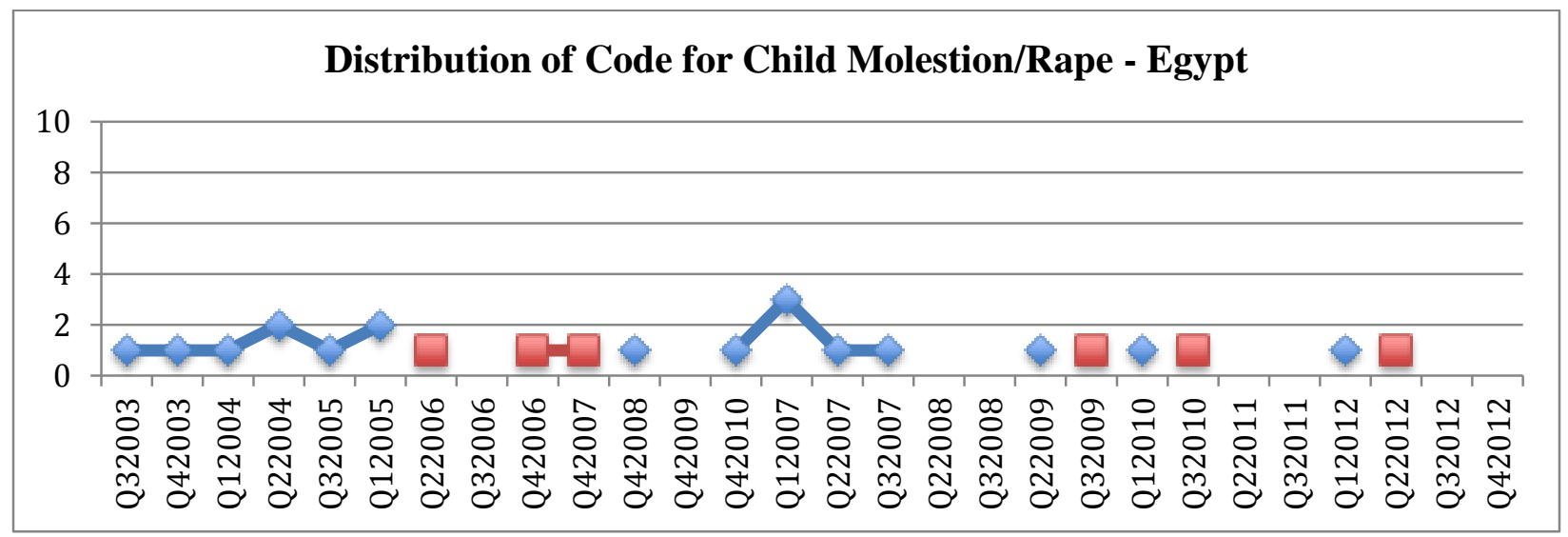

Figure 5: Distribution of Egypt Posts Coded as "Child Molestation/Rape" By Year. In order to condense data take to create more clear distributions, years were divided into quarters. Each post was assigned a quarter based its month and year of issuance.

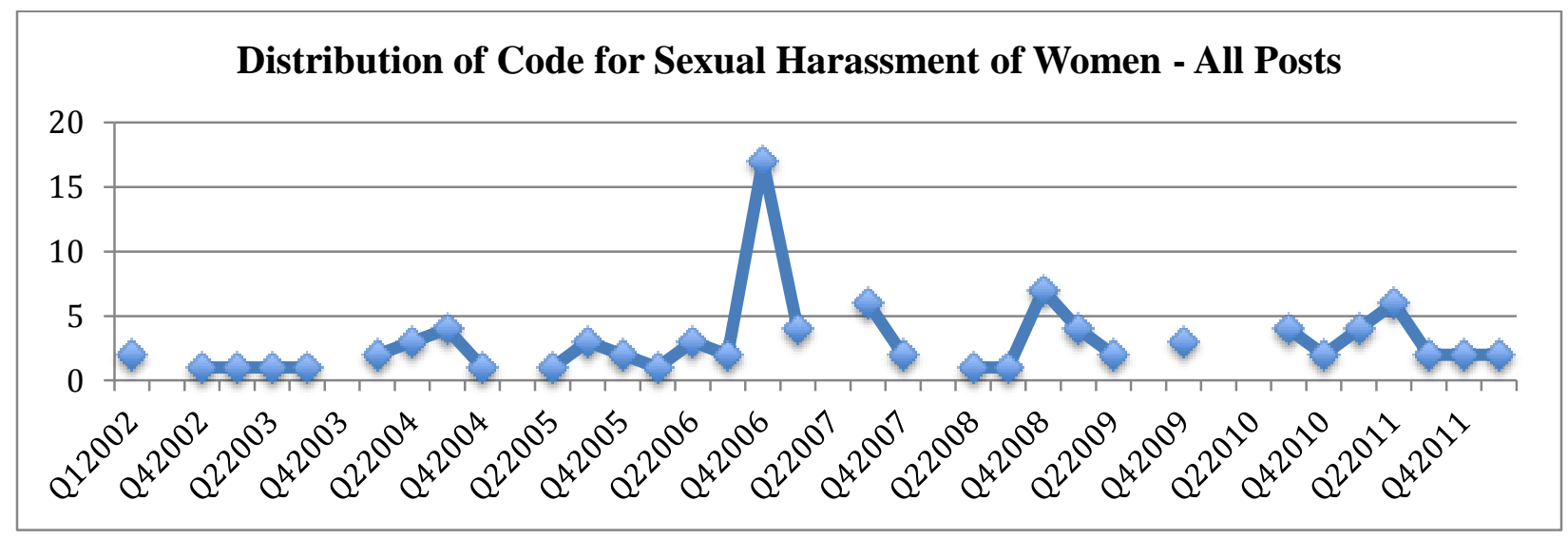

Figure 6: Distribution of All Posts Coded as "Sexual Harassment of Women" By Year. In order to condense data take to create more clear distributions, years were divided into quarters. Each post was assigned a quarter based its month and year of issuance. 


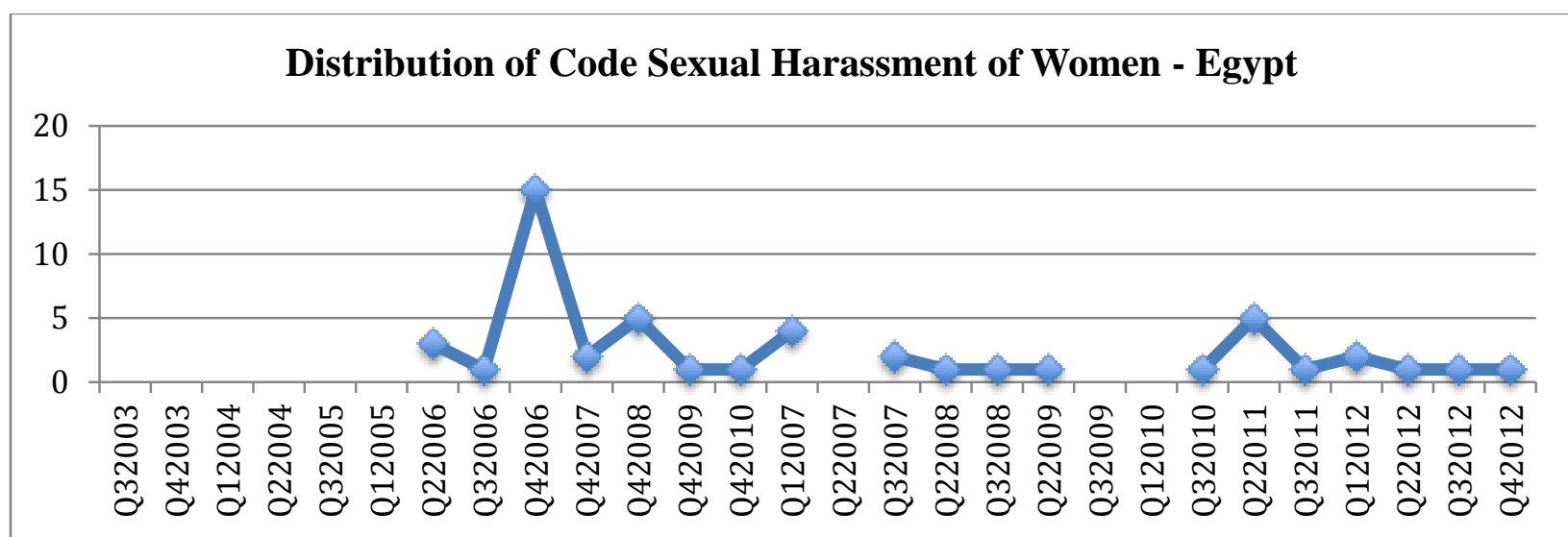

Figure 7: Distribution of Egyptian Posts Coded as "Sexual Harassment of Women" By Year. In order to condense data take to create more clear distributions, years were divided into quarters. Each post was assigned a quarter based its month and year of issuance.

\begin{tabular}{|l|r|r|r|r|}
\hline THEME & \multicolumn{2}{l|l}{$\begin{array}{l}\text { Coded for All } \\
\text { Posts }\end{array}$} & $\begin{array}{l}\text { Coded for } \\
\text { Egypt }\end{array}$ & Frequency \\
\hline Child Molestation \& Rape & 132 & $57 \%$ & 24 & $32 \%$ \\
\hline Sexual Harassment of Women & 98 & $42 \%$ & 49 & $66 \%$ \\
\hline Rape & 19 & $8 \%$ & 8 & $11 \%$ \\
\hline Muaksa & 18 & $8 \%$ & 11 & $15 \%$ \\
\hline Zina & 22 & $9 \%$ & 2 & $3 \%$ \\
\hline Teen/Youth Exploration & 10 & $4 \%$ & 1 & $1 \%$ \\
\hline Parental Responsibility & 82 & $35 \%$ & 14 & $19 \%$ \\
\hline Homosexuality/Sexual Deviation & 70 & $30 \%$ & 10 & $14 \%$ \\
\hline Sexual Harassment of Men & 7 & $3 \%$ & 3 & $4 \%$ \\
\hline State Violence & 4 & $2 \%$ & 2 & $3 \%$ \\
\hline Power/Authority/Control & 10 & $4 \%$ & 6 & $8 \%$ \\
\hline Mob Assault & 6 & $3 \%$ & 6 & $8 \%$ \\
\hline Total Codes & 478 & & 136 & \\
\hline
\end{tabular}

Table 1: Frequency of Coded Themes, Minus Subthemes; N-233 for All Posts, N=74 for Egypt 